\title{
Zastupljenost sindroma izgaranja kod medicinskih sestara i tehničara na primarnoj i sekundarnoj razini zdravstvene zaštite
}

\section{Representation of burnout syndrome in nurses and technicians at primary and secondary levels of health care}

\author{
Silvija Matuzić', Radoslav Kosić2,3 \\ 'Zavod za hitnu medicinu Zagrebačke županije, Matice hrvatske bb, 10410 Velika Gorica/ Department of Emergency Medicine of Zagreb County, Matice \\ hrvatske bb, 10410 Velika Gorica \\ ${ }^{2}$ Klinički Bolnički centar Rijeka, Klinika za pedijatriju, Istarska 43, 51000 Rijeka, Hrvatska/ University Hospital Center Rijeka, Clinic for pediatric, Istarska 43, \\ 51000 Rijeka, Croatia \\ ${ }^{3}$ Fakultet zdravstvenih studija Rijeka, Sveučilište Rijeka, Viktora cara Emina 5, 51000 Rijeka, Hrvatska/ Faculty of Health Studies Rijeka, Univesity of Rijeka, \\ Viktora cara Emina 5, 51000 Rijeka, Croatia
}

\section{Sažetak}

Uvod: Sestrinska profesija predstavlja fizički, psihički, emocionalno i duhovno iscrpljujući te zahtjevan posao. Potreba pružanja usluga u zdravstvenoj skrbi u stalnom je porastu, uključujući sve zahtjevnija očekivanja od medicinskih sestara. Prema rezultatima istraživanja Svjetske zdravstvene organizacije o najstresnijim zanimanjima, sestrinski posao zauzima visoko četvrto mjesto.

Cilj istraživanja: Cilj je istraživanja utvrditi subjektivne i objektivne dimenzije koje utječu na sindrom izgaranja medicinskih sestara i tehničara na primarnoj i sekundarnoj razini zdravstvene zaštite na području grada Karlovca.

Ispitanici i metode: Istraživanje je provedeno u Domu zdravlja Karlovac i Općoj bolnici Karlovac. U istraživanje su uključene medicinske sestre i medicinski tehničari. Anonimni upitnik ispunilo je 65 ispitanika, od čega 30 ispitanika zaposlenih u Domu zdravlja Karlovac i 35 ispitanika zaposlenih u Općoj bolnici Karlovac. U istraživanju je korišten Upitnik za određivanje sindroma izgaranja na poslu.

Rezultati: Rezultati istraživanja pokazuju da ne postoji statistički značajna razlika u zastupljenosti sindroma izgaranja s obzirom na primarnu i sekundarnu razinu zdravstvene zaštite, prema dobi i spolu, razini obrazovanja te rukovodećem radnom mjestu. Nadalje, rezultati pokazuju da je kod ispitanika koji imaju više godina radnog staža niža zastupljenost sindroma izgaranja, dok su stariji ispitanici više mrzovoljni, brže postanu razdražljivi i očekuju više od ljudi koji ih okružuju. Ispitanici višeg stupnja obrazovanja u većoj mjeri osjećaju da rade sve više, a manje su učinkoviti. Rezultati ukazuju na to da je 84,6 \% ispitanika ovog istraživanja zahvaćeno sindromom izgaranja.

Zaključak: Kod zaposlenika koji imaju više godina radnog staža verificiran je manji stupanj sindroma izgaranja. Moguće je da je to povezano s većim stupnjem zadovoljstva (veći stupanj spremnosti za napredovanjem i trajnom edukacijom) što predstavlja osnovu za određivanje stupnja kvalitete radnog okruženja i prevenciju sindroma izgaranja.

Ključne riječi: izgaranje, medicinska sestra / tehničar, primarna / sekundarna zaštita

Kratak naslov: Zastupljenost sindroma izgaranja medicinskih djelatnika u primarnoj i sekundarnoj zaštiti

\begin{abstract}
Introduction: The nursing profession represents a physically, mentally, emotionally, spiritually exhausting, and demanding job. The need to provide health care services is constantly growing, including increasingly demanding expectations of nurses. According to the results of the World Health Organization's research on the most stressful occupations, nursing takes a high fourth place.

Aim: This paper aims to determine the subjective and objective dimensions that affect the burnout syndrome of nurses and technicians at the primary and secondary level of health care in Karlovac.
\end{abstract}

Subjects and Methods: The study was conducted at the Health Center Karlovac and General Hospital Karlovac. Nurses and technicians were included in the research. An anonymous questionnaire was completed by 65 respondents, of whom 30 were employees of the Health Center Karlovac and 35 were employed at the General Hospital Karlovac. The survey used a Questionnaire to determine burnout syndrome at work.

Results: The results show that there is no statistically significant difference in the incidence of burnout syndrome concerning primary and secondary health care levels, considering age and gender, education level, and managerial workplace. Furthermore, the results show that respondents who have more years of work experience show a lower prevalence of burnout syndrome, whereas older respondents are more cranky, quick-tempered, and expect more from the people around them. Respondents with higher education feel that they are doing more, but less effective. The results indicate that $84.6 \%$ of the respondents in this study are affected by burnout syndrome.

Conclusion: Employees with more years of service experience have a lower level of burnout syndrome verified, and that may also be associated with a higher degree of satisfaction (greater degree of readiness for advancement and continuing education), which is the basis for determining the quality of the work environment and the prevention of burnout syndrome.

Keywords: burnout, nurse/technician, primary / secondary care Runing head: Incidence of primary care and secondary care burnout syndrome 


\section{Uvod}

Sindrom izgaranja reakcija je na stres uslijed velikih očekivanja i prevelikih davanja. Smatra se da su izgaranju više sklone osobe koje teže višoj poziciji na radnom mjestu, pretjerano ambiciozne i odgovorne osobe te one koje su bezrezervno predane poslu i radnu sredinu doživljavaju kao razlog postojanja. Za uvođenje termina „izgaranje na poslu" zaslužan je Freudenbeger koji smatra da je izgaranje na poslu stanje iscrpljenosti nastalo pod utjecajem dugotrajnog stresa i napora ne ostavljajući dovoljno vremena za odmor i relaksaciju [1]. U suradnji sa psihologom Gailom Northom definirao je faze procesa izgaranja na poslu. Autori navode da se u početku javlja potreba za dokazivanjem, zatim se počinje raditi teže, zanemaruju se vlastite potrebe, javlja se premještanje sukoba, ispitivanje vlastitih vrijednosti, cinizam i agresija, socijalno povlačenje, promjene ponašanja koje su vidljive drugim ljudima, a potom dolazi do osjećaja unutarnje praznine i na kraju do sindroma izgaranja [2]. Tumači li se izgaranje kao odgovor organizma na stresne situacije, treba biti svjestan da upravo taj stres vrši pritisak na ljudski organizam na način da potiče povećanu aktivnost moždanih stanica, što je pak povezano $\mathrm{s}$ pojačanim lučenjem hormona nadbubrežne žlijezde te izazivanjem ubrzanog rada srca i disanja. Uzimajući sve to $u$ obzir, postaje jasno da tijelo daje odgovore u vidu tjelesnih simptoma pa se osoba zahvaćena sindromom izgaranja na kraju mora boriti s nizom poremećaja i bolesti. Posljedice dovode do smanjene učinkovitosti na radnome mjestu, a samim time i smanjenim zadovoljstvom te povećanom stopom bolovanja.

Reagirajući na stres, neuroendokrinološki odgovor na osobnu percepciju stresa utječe na pojavu i razvoj sindroma izgaranja. Situacije je potrebno procijeniti uzimajući u obzir koliko je pojedina situacija stresna i značajna za pojedinca i može li se na nju utjecati. Tijekom radnog vremena obavezno treba osigurati stanku za odmor i zadatke kategorizirati po prioritetima. Ciljevi rada moraju biti realni i izvedivi, treba delegirati poslove koje je moguće, a posebno je važno znati reći "Ne". Treba biti svjestan da se ne može uvijek, odmah i na način na koji se to zahtijeva, svima biti na raspolaganju. Odnosi s kolegama trebaju biti pozitivni. Jedan od načina stvaranja pozitivne radne sredine je povećanje broja zaposlenih. Potrebno je u privatnom životu odrediti vrijeme za opuštanje, primjerice čitanje, slušanje glazbe i/ili bavljenje sportom. U težim slučajevima poželjno je uvesti psihoterapijsku podršku i savjetovanje. Psihoedukacija kao preventivna metoda pomaže boljem razumijevanju trenutne situacije, boljem suočavanju s novonastalom situacijom i što uspješnijem nošenju s problemima. Usmjerena je na otklanjanje simptoma, ponovnu uspostavu funkcioniranja $i$ porast vrijednosti pojedinca [3].

Sestrinstvo kao profesija predstavlja fizički, psihički, emocionalno i duhovno iscrpljujući te zahtjevan posao. Potreba pružanja usluga u zdravstvenoj skrbi u stalnom je porastu, uključujući sve zahtjevnija očekivanja od medicinskih sestara. Prema rezultatima istraživanja najstresnijih zanimanja Svjetske zdravstvene organizacije, sestrinski posao zauzima visoko četvrto mjesto [4]. Od zdravstvenih radnika (kojih često nema dovoljno) očekuje se sve više, što do- prinosi nezadovoljstvu radnom sredinom. Udio sestrinskih postupaka iznosi oko $70 \%$ svih zdravstvenih postupaka [5]. Odgovornost za pacijente i zdravstvenu njegu, donošenje racionalnih odluka u procesu zdravstvene njege, brojni nepredvidivi zadaci, smjenski rad, rad tijekom blagdana te kontakti s oboljelom osobom i njezinom obitelji, sestrinski posao čine iznimno zahtjevnim.

Friganović i suradnici 2017. godine proveli su istraživanje na osnovi kojega su zaključili da je povezanost utjecaja stresa kod zdravstvenih radnika s nastankom somatskih bolesti još uvijek nedovoljno istražen. Također su utvrdili da se relativno malo spominje u obrazovnom kurikulumu profila zdravstvenih djelatnika iako postoji sve veća potreba za primjenom i pružanjem psihološke podrške te za razvojem programa prevencije sindroma izgaranja [6]. Isti autori zaključuju da zbog posljedica izloženosti stresu zdravstvenih djelatnika (prevelike obaveze, izostanak priznanja za trud, često susretanje sa smrti, osobno percipiranje stresa), sve češće dolazi do izostanaka s radnog mjesta i promjena kadra. Navedeno posljedično negativno utječe na pružanje kvalitetne sestrinske skrbi [6].

Postoji više aktivnosti koje se mogu primijeniti na lokalnoj, regionalnoj ili nacionalnoj razini kako bi se poboljšala kvaliteta zdravstvenog sustava, a time posljedično prevenirao razvoj sindroma izgaranja. Ispitivanje o izgaranju na poslu medicinskih sestara potrebno je provoditi jednom godišnje kao standard kvalitete. Ovo je istraživanje potaknuto potrebom ispitivanja postojanja moguće razlike izgaranja na poslu na primarnoj i sekundarnoj razini zdravstvene zaštite.

\section{Ciljevi}

Osnovni je cilj istraživanja ispitati zastupljenost sindroma izgaranja medicinskih sestara na primarnoj i sekundarnoj razini zdravstvene zaštite.

Specifični su ciljevi:

- ispitati razliku zastupljenosti sindroma izgaranja prema spolu ispitanika;

- ispitati razliku zastupljenosti sindroma izgaranja prema životnoj dobi ispitanika;

- ispitati razliku zastupljenosti sindroma izgaranja prema bračnom statusu ispitanika;

- ispitati razliku zastupljenosti sindroma izgaranja prema stupnju obrazovanja ispitanika;

- ispitati razliku zastupljenosti sindroma izgaranja s obzirom na funkciju na radnom mjestu rukovoditelja;

- ispitati razliku zastupljenosti sindroma izgaranja prema godinama radnog staža.

Hipoteza 1: Zastupljenost sindroma izgaranja veća je na sekundarnoj razini zdravstvene zaštite u odnosu na primarnu razinu zdravstvene zaštite.

Hipoteza 2: Medicinske sestre više su zahvaćene sindromom izgaranja u odnosu na medicinske tehničare.

\section{Ispitanici i metode}

$\mathrm{U}$ ispitivanju je sudjelovalo ukupno 65 ispitanika od kojih 30 ispitanika čine medicinske sestre zaposlene u Domu 
zdravlja Karlovac, a 35 ispitanika čine medicinske sestre zaposlene u Općoj bolnici Karlovac.

Korišten je Upitnik za određivanje sindroma izgaranja Američkog psihologijskog društva (engl. American Psychological Association). Upitnik je preuzet s web-stranice [7]. Dopunjen je na način da su izvorniku dodana sociodemografska pitanja (dob, spol, stupanj obrazovanja, dužina radnog staža, bračni status).

$\mathrm{U}$ anketnom upitniku korištena je numerička mjerna skala. Ispitanik je na skali Likertovog tipa od 1 do 5 procjenjivao stupanj izloženosti stresu. Raspon bodova: do 25 bodova smatra se da je sindrom izgaranja izostao; od 26 do 35 bodova - ispitanik je u području rizika; od 36 do 50 bodova - ispitanik je kandidat za razvoj sindroma izgaranja; od 51 do 65 bodova - ispitanik je zahvaćen sindromom izgaranja; iznad 65 bodova - ispitanik se smatra sagorjelim. Istraživanje je provedeno u kolovozu 2018. godine.

Apsolutne i relativne frekvencije korištene su za prikaz kategorijskih podataka. Kolmogorov-Smirnovljevim testom ispitana je normalnost raspodjele numeričkih varijabli. Numerički podaci koji se raspodjeljuju u skladu s normalnom raspodjelom opisani su aritmetičkom sredinom i standardnom devijacijom, a oni koji se ne raspodjeljuju prema normalnoj raspodjeli opisani su medijanom i granicama interkvartilnog raspona.

Statistička značajnost razlike kategorijskih varijabli testirana je Hi-2 testom te, po potrebi, Fisherovim egzaktnim testom. U slučaju malih frekvencija ( $f<5$ ), prije analiza provedeno je spajanje odgovarajućih susjednih rubrika (čestica). U analizi tablica kontingencije 2 × 2 primijenjena je Yatesova korekcija. Budući da su u većini slučajeva promatrane skupine numeričkih podataka sadržavale manje od 20 podataka, za njihovu analizu korištene su neparametrijske statističke metode. Razlike između dviju nezavisnih numeričkih varijabli ispitane su Mann-Whitneyjevim testom, a razlike između triju ili više nezavisnih numeričkih varijabli testirane su Kruskal-Wallisovim ANOVA testom. Ocjena povezanosti između numeričkih parametara ispitana je Spearmanovim ( $r$; rho) koeficijentom korelacije. Rezultati su interpretirani na razini statističke značajnosti $p=0,05$.

Svi izračuni i statističke analize učinjeni su primjenom programskog paketa Statistica (StatSoft Inc.,StatSoft, Tulsa, SAD) verzija 13.0.

\section{Rezultati}

\section{Sociodemografski podaci}

U provedenom istraživanju sudjelovalo je ukupno 65 ispitanika, među kojima je 47 žena $(72,3 \%)$ i 18 muškaraca $(27,7$ \%). Najveći broj ispitanika, njih 18 (27,7 \%), životne je dobi 31 - 40 godina, a slijedi ih 15 ispitanika (23,1\%) starosti 41 - 50 godina. Ukupno 13 ispitanika (20\%) staro je između 51 i 60 godina, a 12 ispitanika (18,4 \%) ima između 19 i 30 godina. Najmanje ispitanika, njih 7, starije je od 60 godina (10,8 \%). U braku je 48 ispitanika (73,9\%), neudanih/neoženjenih je 8 (12,3\%), rastavljenih je $4(6,1 \%)$, a udovaca/ udovica je ukupno 5 (7,7\%). Najviše ispitanika ima srednju stručnu spremu, njih 41 (63,1\%), 19 ispitanika (29,2 \%) su prvostupnici ili imaju završenu višu školu. Najmanje ispitanika, njih 5 (7,7 \%), završilo je diplomski studij. U primarnoj zdravstvenoj zaštiti zaposleno je 30 ispitanika (46,2 \%), a u sekundarnoj zdravstvenoj zaštiti 35 ispitanika (53,8 \%). Većina ispitanika, njih 56 (86,2 \%), nije zaposlena na radnom mjestu rukovoditelja. Na rukovodećim je pozicijama zaposleno 9 ispitanika (13,8\%). Prema godinama radnog staža ispitanici su podijeljeni u četiri skupine. U svakoj od tih skupina nalazi se približno jednak broj ispitanika: u skupini do 10 godina radnog staža je 16 ispitanika (24,6\%), u skupini 11 - 20 godina te u skupini 21 - 30 godina radnog staža isto je po 16 ispitanika, a 17 ispitanika $(26,2 \%)$ ima 30 i više godina radnog staža.

Prema podacima iz tablice [Tablica 1] na pitanja o sindromu izgaranja 22 ispitanika (33,8 \%) odgovaraju da često imaju premalo vremena za zabavu. Premalo podrške i pomoći osjećaju 24 ispitanika (36,9\%), 30 se ispitanika (46,2 $\%)$ ponekad lako zamara i osjeća iscrpljeno. Ukupno 27 ispitanika (41,5 \%) ponekad ima osjećaj da radi sve više, a da ništa ne napravi. Ukupno 26 ispitanika (40 \%) ponekad je zajedljivo i razočarano svijetom. Nitko od ispitanika nije izjavio da se uvijek osjeća žalosno, a da ne zna zašto. Rijetko je zaboravljivo (ne odu na dogovoreni sastanak, gube stvari i slično) ukupno 26 ispitanika (40\%). Da se ponekad osjećaju kao da provode sve manje vremena s prijateljima i obitelji, izjasnilo se 28 ispitanika (43,1\%). Nitko od ispitanika nije uvijek prezauzet za uobičajene potrebe (telefonski razgovori, čitanje, pisanje i drugo). Ukupno 34 ispitanika $(52,3 \%)$ izjavila su da su rijetko u stanju u kojem se uvijek osjećaju loše ili bolesno. Da se nikada ne osjeća smeteno na kraju radnog dana, navodi 25 ispitanika (38,4\%). Ukupno je 5 ispitanika (6,2 \%) izjavilo da ih seksualne aktivnosti uvijek opterećuju i stvaraju više problema nego inače. Takvih problema nikada nema 28 ispitanika (43,1\%). Najveći broj ispitanika, njih 32,3\%, nikad se ne osjeća kao da ima malo toga za reći ljudima. Ispitanika koji se samo ponekad tako osjećaju je 33,8 \%. Ispitanici se u najvećoj mjeri nikad ili rijetko uzrujaju kada im kažu da ne izgledaju dobro (33,8 \%). Najveći udio ispitanika nikada nije (32,3\%) ili je rijetko (36,9\%) mrzovoljan, brzo raspaljiv ili očekuje više od ljudi oko sebe.

Iz tablice [Tablica 2] vidljivo je da je prosječna vrijednost sindroma izgaranja nešto veća kod žena nego kod muškaraca te kod ispitanika zaposlenih u sekundarnoj, u odnosu na one zaposlene $u$ primarnoj zdravstvenoj zaštiti, ali se te razlike nisu pokazale statistički značajnima (Mann-Whitney test; $p>0,005)$.

Razlike srednjih vrijednosti sindroma izgaranja nisu se pokazale statistički značajnima ni među različitim dobnim skupinama, skupinama različitog stupnja obrazovanja, različitog trajanja radnog staža (Tablica 2; Kruskal-Wallis ANOVA test; $p>0,05)$, niti između skupine ispitanika na radnom mjestu rukovoditelja i skupine ispitanika koja nije na rukovodećem radnom mjestu (Tablica 2; Mann-Whitney test; $p=0,99$ ).

Statistički značajna razlika srednjih vrijednost sindroma izgaranja utvrđena je samo za skupine različitih bračnih statusa: neudani / neoženjeni ispitanici imaju manju vrijednost sindroma izgaranja u odnosu na ostale ispitanike (Tablica 2; Kruskal Wallis ANOVA test; $p=0,005$ ). 
TABLICA [1] Prikaz raspodjele odgovora za procjenu sindroma izgaranja

\begin{tabular}{|c|c|c|c|c|}
\hline & \multicolumn{4}{|c|}{ Broj (\%) ispitanika } \\
\hline & Nikada & Rijetko & Ponekad & Često \\
\hline Događa li vam se da imate premalo vremena za zabavu? & $4(6,2)$ & $12(18,5)$ & $19(29,2)$ & $22(33,8)$ \\
\hline Osjećate li da imate premalo podrške i pomoći ? & $7(10,8)$ & $18(27,7)$ & $24(36,9)$ & $15(23,1)$ \\
\hline Zamarate li se lako i osjećate li se iscrpljeno? & $3(4,6)$ & $12(18,4)$ & $30(46,2)$ & $18(27,7)$ \\
\hline Imate li osjećaj da radite sve više, a da ništa ne napravite? & $9(13,8)$ & $20(30,8)$ & $27(41,5)$ & $7(10,8)$ \\
\hline Jeste li zajedljivi i sve više razočarani svijetom? & $10(15,4)$ & $17(26,2)$ & $26(40,0)$ & $11(16,9)$ \\
\hline Osjećate li se žalosno, a ne znate zašto? & $21(32,3)$ & $20(30,8)$ & $21(32,3)$ & $3(4,6)$ \\
\hline $\begin{array}{l}\text { Jeste li zaboravljivi, ne odete na dogovoreni sastanak, } \\
\text { često nešto izgubite...? }\end{array}$ & $22(33,9)$ & $26(40,0)$ & $11(16,9)$ & $6(9,2)$ \\
\hline Provodite li sve manje vremena s prijateljima i obitelji ? & $10(15,4)$ & $15(23,1)$ & $28(43,1)$ & $12(18,4)$ \\
\hline $\begin{array}{l}\text { Jeste li prezauzeti za uobičajene potrebe (telefonski razgovori, } \\
\text { čitanje, pisanje...)? }\end{array}$ & $10(15,4)$ & $17(26,2)$ & $20(30,8)$ & $18(27,7)$ \\
\hline Osjećate li se uvijek loše ili ste stalno bolesni ? & $13(20,0)$ & $34(52,3)$ & $12(18,5)$ & $6(9,2)$ \\
\hline Osjećate li se smeteno na kraju radnog dana? & $25(38,4)$ & $20(30,8)$ & $11(16,9)$ & $7(10,8)$ \\
\hline $\begin{array}{l}\text { Opterećuju li Vas seksualne aktivnosti i stvaraju više problema } \\
\text { nego inače? }\end{array}$ & $28(43,1)$ & $19(29,2)$ & $11(16,9)$ & $3(4,6)$ \\
\hline Osjećate li da imate malo toga reći ljudima? & $21(32,3)$ & $17(26,2)$ & $22(33,8)$ & $4(6,2)$ \\
\hline Uzrujate li se kada Vam u zadnje vrijeme kažu da ne izgledate dobro? & $22(33,8)$ & $22(33,8)$ & $18(27,7)$ & $2(3,1)$ \\
\hline Jeste li mrzovoljni, brzo raspaljivi, očekujete li više od ljudi oko Vas? & $21(32,3)$ & $24(36,9)$ & $14(21,5)$ & $4(6,2)$ \\
\hline
\end{tabular}

TABLICA [2] Rezultati ocjene srednjih vrijednosti sindroma izgaranja

\begin{tabular}{|c|c|c|c|c|c|}
\hline $\begin{array}{l}\text { Sindrom } \\
\text { izgaranja }\end{array}$ & $\begin{array}{l}\text { Medijan } \\
\text { (interkvartilni } \\
\text { raspon) }\end{array}$ & $\mathbf{p}$ & $\begin{array}{l}\text { Sindrom } \\
\text { izgaranja }\end{array}$ & $\begin{array}{l}\text { Medijan } \\
\text { (interkvartilni } \\
\text { raspon) }\end{array}$ & $\mathbf{p}$ \\
\hline Spol & & & Mjesto rada & & \\
\hline $\begin{array}{l}\text { Žene } \\
\text { Muškarci }\end{array}$ & $\begin{array}{l}36(31-43) \\
32(22-42)\end{array}$ & $0,18^{*}$ & $\begin{array}{l}\text { Primarna zdravstvena zaštita } \\
\text { Sekundarna zdravstvena zaštita }\end{array}$ & $\begin{array}{l}33(29-42) \\
36(30-48)\end{array}$ & $0,17^{*}$ \\
\hline Dob (godine) & & & Radno mjesto rukovoditelja & & \\
\hline $\begin{array}{l}19-30 \\
31-40 \\
41-50 \\
51-60 \\
60+\end{array}$ & $\begin{array}{c}28(21-46) \\
39,5(33-42) \\
33(30-43) \\
32(30-33) \\
39(29-50)\end{array}$ & $0,38^{* *}$ & $\begin{array}{l}\mathrm{Da} \\
\mathrm{Ne}\end{array}$ & $\begin{array}{l}33(32-40) \\
33(29-43)\end{array}$ & $0,99^{*}$ \\
\hline Bračni status & & & Radni staž (godine) & & \\
\hline $\begin{array}{l}\text { udata/oženjen } \\
\text { neudata/neoženjen } \\
\text { rastavljena/rastavljen } \\
\text { udovac/udovica }\end{array}$ & $\begin{array}{c}36,5(32-43) \\
21,5(19-25,5) \\
32(31-37) \\
39(33-50) \\
\end{array}$ & $0,005 * *$ & $\begin{array}{l}1-10 \\
11-20 \\
21-30 \\
31-40 \\
\end{array}$ & $\begin{array}{c}29,5(21-43) \\
40(35-42) \\
33(29,5-42,5) \\
33(31-48) \\
\end{array}$ & $0,12^{* *}$ \\
\hline \multicolumn{6}{|l|}{ Stupanj obrazovanja } \\
\hline $\begin{array}{l}\text { SSS } \\
\text { VŠS (viša škola / prvostupnik) } \\
\text { VSS (diplomski studij) }\end{array}$ & $\begin{array}{l}32(27-45) \\
34(33-43) \\
41(40-42)\end{array}$ & $0,237^{* *}$ & & & \\
\hline
\end{tabular}

\footnotetext{
*Mann-Whitney test

**Kruskal-Wallis ANOVA test
}

Iz tablice [Tablica 3] vidljivo je da nema statistički značajne razlike raspodjele prema stupnju sindroma izgaranja između muškaraca i žena (Hi-2 test; $p=0,55)$.
Iz tablice [Tablica 4] vidljivo je da rezultati raspodjele ispitanika prema stupnju sindroma izgaranja i dobi nisu statistički značajni (Hi-2 test; $p=0,27)$. 
TABLICA [3] Rezultati raspodjele ispitanika prema stupnju sindroma izgaranja i spolu

\begin{tabular}{|c|c|c|c|c|c|c|}
\hline \multirow{3}{*}{ Spol } & \multicolumn{6}{|c|}{ Broj ispitanika (\%) prema sindromu izgaranja } \\
\hline & $\begin{array}{l}\text { izostanak } \\
\text { sindroma }\end{array}$ & $\begin{array}{c}\text { ispitanik u } \\
\text { području rizika }\end{array}$ & $\begin{array}{c}\text { kandidat za razvoj } \\
\text { sindroma }\end{array}$ & $\begin{array}{c}\text { ispitanik zahvaćen } \\
\text { sindromom }\end{array}$ & $\begin{array}{c}\text { ispitanik se smatra } \\
\text { sagorjelim }\end{array}$ & Ukupno \\
\hline & $<25$ & $26-35$ & $36-50$ & $51-65$ & $>65$ & \\
\hline Muškarci & $6(33,3)$ & $5(27,8)$ & $4(22,2)$ & $3(16,7)$ & $0(0,0)$ & $18(27,7)$ \\
\hline Žene & $4(8,5)$ & $19(40,4)$ & $22(46,8)$ & $2(4,3)$ & $0(0,0)$ & $47(72,3)$ \\
\hline Ukupno & $10(15,4)$ & $24(36,9)$ & $26(40,0)$ & $5(7,7)$ & $0(0,0)$ & $65(100)$ \\
\hline
\end{tabular}

*Hi-2 test; Yates korekcija

TABLICA [4] Rezultati raspodjele ispitanika prema stupnju sindroma izgaranja i dobi

\begin{tabular}{|c|c|c|c|c|c|c|}
\hline \multirow{3}{*}{ Dob (godine) } & \multicolumn{6}{|c|}{ Broj ispitanika (\%) prema sindromu izgaranja } \\
\hline & $\begin{array}{l}\text { izostanak } \\
\text { sindroma }\end{array}$ & $\begin{array}{c}\text { ispitanik u } \\
\text { području rizika }\end{array}$ & $\begin{array}{l}\text { kandidat za } \\
\text { razvoj sindroma }\end{array}$ & $\begin{array}{l}\text { ispitanik } \\
\text { zahvaćen } \\
\text { sindromom }\end{array}$ & $\begin{array}{c}\text { ispitanik } \\
\text { se smatra } \\
\text { sagorjelim }\end{array}$ & Ukupno \\
\hline & $<25$ & $36-50$ & $26-35$ & $51-65$ & $>65$ & \\
\hline $19-30$ & $6(50,0)$ & $1(8,3)$ & $4(33,4)$ & $1(8,3)$ & $0(0,0)$ & $12(18,5)$ \\
\hline $31-40$ & $1(5,6)$ & $5(27,8)$ & $10(55,6)$ & $2(11,1)$ & $0(0,0)$ & $18(27,7)$ \\
\hline $41-50$ & $2(13,3)$ & $6(40,0)$ & $6(40,0)$ & $1(6,7)$ & $0(0,0)$ & $15(23,1)$ \\
\hline $51-60$ & $1(7,7)$ & $9(69,2)$ & $3(23,1)$ & $0(0,0)$ & $0(0,0)$ & $13(20,0)$ \\
\hline $60+$ & $0(0,0)$ & $3(42,8)$ & $3(42,8)$ & $1(14,4)$ & $0(0,0)$ & $7(10,8)$ \\
\hline Ukupno & $10(15,4)$ & $24(36,9)$ & $26(40,0)$ & $5(7,7)$ & $0(0,0)$ & $65(100)$ \\
\hline
\end{tabular}

*Hi-2 test; Yates korekcija

TABLICA [5] Rezultati raspodjele ispitanika prema stupnju sindroma izgaranja i bračnom statusu

\begin{tabular}{|c|c|c|c|c|c|c|}
\hline \multirow{3}{*}{ Bračni status } & \multicolumn{6}{|c|}{ Broj ispitanika (\%) prema sindromu izgaranja } \\
\hline & $\begin{array}{l}\text { izostanak } \\
\text { sindroma }\end{array}$ & $\begin{array}{c}\text { ispitanik u } \\
\text { području rizika }\end{array}$ & $\begin{array}{l}\text { kandidat } \\
\text { za razvoj } \\
\text { sindroma } \\
\end{array}$ & $\begin{array}{c}\text { ispitanik } \\
\text { zahvaćen } \\
\text { sindromom }\end{array}$ & $\begin{array}{c}\text { ispitanik } \\
\text { se smatra } \\
\text { sagorjelim }\end{array}$ & Ukupno \\
\hline & $<25$ & $36-50$ & $26-35$ & $51-65$ & $>65$ & \\
\hline udata/oženjen & $4(8,3)$ & $18(37,5)$ & $21(43,8)$ & $5(10,4)$ & $0(0,0)$ & $48(73,8)$ \\
\hline neudata/neoženjen & $6(75,0)$ & $1(12,5)$ & $1(12,5)$ & $0(0,0)$ & $0(0,0)$ & $8(12,3)$ \\
\hline rastavljena/rastavljen & $0(0,0)$ & $3(75,0)$ & $1(25,0)$ & $0(0,0)$ & $0(0,0)$ & $4(6,2)$ \\
\hline udovac/udovica & $0(0,0)$ & $2(40,0)$ & $3(60,0)$ & $0(0,0)$ & $0(0,0)$ & $5(7,7)$ \\
\hline Ukupno & $10(15,4)$ & $24(36,9)$ & $26(40,0)$ & $5(7,7)$ & $0(0,0)$ & $65(100)$ \\
\hline
\end{tabular}

*Fisherov egzaktni test

U tablici [Tablica 5] prikazani su rezultati raspodjele ispitanika prema stupnju sindroma izgaranja i bračnom statusu iz kojih je vidljivo da nema statistički značajne razlike raspodjele prema stupnju sindroma izgaranja između ispitanika u braku i onih koji nisu u braku - neudani/neoženjeni, rastavljeni i udovci (Fisherov egzaktni test; $p=0,07$ ). Kada se promatraju samo ispitanici u braku i skupina neudanih/ neoženjenih, razlika je statistički značajna: više je ispitanika koji su u braku i imaju viši stupanj sindroma izgaranja u odnosu na neudane/neoženjene (Fisherov egzaktni test; $p$ $=0,033$ ).
Iz tablice [Tablica 6] vidljivo je da raspodjela ispitanika prema stupnju sindroma izgaranja i trenutnom stupnju obrazovanja nije statistički značajna (Hi-2 test; $p=0,59$ ).

U tablici [Tablica 7] prikazani rezultati ukazuju da je stupanj sindroma izgaranja podjednako raspodijeljen kod ispitanika koji su zaposleni na radnom mjestu rukovoditelja, kao i kod onih koji nisu na rukovodećim pozicijama (Fisherov egzaktni test; $p=0,56)$.

Iz tablice [Tablica 8] vidljivo je da nema statistički značajne razlike u raspodjeli sindroma izgaranja između ispitani- 
TABLICA [6] Rezultati raspodjele ispitanika prema stupnju sindroma izgaranja i obrazovanju

\begin{tabular}{|c|c|c|c|c|c|c|}
\hline \multirow{3}{*}{ Obrazovanje } & \multicolumn{6}{|c|}{ Broj ispitanika (\%) prema sindromu izgaranja } \\
\hline & $\begin{array}{l}\text { izostanak } \\
\text { sindroma }\end{array}$ & $\begin{array}{c}\text { ispitanik u } \\
\text { području } \\
\text { rizika }\end{array}$ & $\begin{array}{l}\text { kandidat } \\
\text { za razvoj } \\
\text { sindroma } \\
\end{array}$ & $\begin{array}{c}\text { ispitanik } \\
\text { zahvaćen } \\
\text { sindromom }\end{array}$ & $\begin{array}{c}\text { ispitanik } \\
\text { se smatra } \\
\text { sagorjelim }\end{array}$ & Ukupno \\
\hline & $<25$ & $36-50$ & $26-35$ & $51-65$ & $>65$ & \\
\hline SSS & $10(24,4)$ & $13(31,7)$ & $14(34,1)$ & $4(9,8)$ & $0(0,0)$ & $41(63,1)$ \\
\hline VŠS (viša škola / prvostupnik) & $0(0,0)$ & $10(52,6)$ & $8(42,1)$ & $1(5,3)$ & $0(0,0)$ & $19(29,2)$ \\
\hline VSS (diplomski studij) & $0(0,0)$ & $1(20,0)$ & $4(80,0)$ & $0(0,0)$ & $0(0,0)$ & $5(7,7)$ \\
\hline Ukupno & $10(15,4)$ & $24(36,9)$ & $26(40,0)$ & $5(7,7)$ & $0(0,0)$ & $65(100)$ \\
\hline
\end{tabular}

*Hi-2 test, Yates korekcija

TABцICA [7] Rezultati raspodjele ispitanika prema stupnju sindroma izgaranja i radnom mjestu rukovoditelja

\begin{tabular}{|c|c|c|c|c|c|c|}
\hline \multirow{3}{*}{ Mjesto rukovoditelja } & \multicolumn{6}{|c|}{ Broj ispitanika (\%) prema sindromu izgaranja } \\
\hline & $\begin{array}{l}\text { izostanak } \\
\text { sindroma }\end{array}$ & $\begin{array}{c}\text { ispitanik u } \\
\text { području } \\
\text { rizika }\end{array}$ & $\begin{array}{l}\text { kandidat } \\
\text { za razvoj } \\
\text { sindroma }\end{array}$ & $\begin{array}{c}\text { ispitanik } \\
\text { zahvaćen } \\
\text { sindromom }\end{array}$ & $\begin{array}{c}\text { ispitanik } \\
\text { se smatra } \\
\text { sagorjelim }\end{array}$ & Ukupno \\
\hline & $<25$ & $26-35$ & $36-50$ & $51-65$ & $>65$ & \\
\hline $\mathrm{Da}$ & $0(0,0)$ & $5(55,6)$ & $4(44,4)$ & $0(0,0)$ & $0(0,0)$ & $9(13,8)$ \\
\hline $\mathrm{Ne}$ & $10(17,9)$ & $19(33,9)$ & $22(39,3)$ & $5(8,9)$ & $0(0,0)$ & $56(86,2)$ \\
\hline Ukupno & $10(15,4)$ & $24(36,9)$ & $26(40,0)$ & $5(7,7)$ & $0(0,0)$ & $65(100)$ \\
\hline
\end{tabular}

*Fisherov egzaktni test

TABLICA [8] Rezultati raspodjele ispitanika prema stupnju sindroma izgaranja i mjestu rada

\begin{tabular}{|c|c|c|c|c|c|c|}
\hline \multirow{3}{*}{ Mjesto rada } & \multicolumn{6}{|c|}{ Broj ispitanika (\%) prema sindromu izgaranja } \\
\hline & $\begin{array}{l}\text { izostanak } \\
\text { sindroma }\end{array}$ & $\begin{array}{l}\text { ispitanik u } \\
\text { području } \\
\text { rizika }\end{array}$ & $\begin{array}{l}\text { kandidat } \\
\text { za razvoj } \\
\text { sindroma }\end{array}$ & $\begin{array}{c}\text { ispitanik } \\
\text { zahvaćen } \\
\text { sindromom }\end{array}$ & $\begin{array}{c}\text { ispitanik } \\
\text { se smatra } \\
\text { sagorjelim }\end{array}$ & Ukupno \\
\hline & $<25$ & $36-50$ & $26-35$ & $51-65$ & $>65$ & \\
\hline Primarna zdravstvena zaštita & $5(16,7)$ & $12(40,0)$ & $12(40,0)$ & $1(3,3)$ & $0(0,0)$ & $30(46,2)$ \\
\hline $\begin{array}{l}\text { Sekundarna zdravstvena } \\
\text { zaštita }\end{array}$ & $5(14,3)$ & $12(34,3)$ & $14(40)$ & $4(11,4)$ & $0(0,0)$ & $35(53,8)$ \\
\hline Ukupno & $10(15,4)$ & $24(36,9)$ & $26(40,0)$ & $5(7,7)$ & $0(0,0)$ & $65(100)$ \\
\hline
\end{tabular}

*Hi-2 test

ka zaposlenih u primarnoj zdravstvenoj zaštiti i ispitanika zaposlenih u sekundarnoj zdravstvenoj zaštiti (Hi-2 test; $p$ $=0,8)$.

Rezultati iz tablice [Tablica 9] nisu pokazali statističku značajnost u raspodjeli sindroma izgaranja među ispitanicima različitog radnog staža (Hi-2 test; $p=0,54)$.

Povezanost dobi, stupnja obrazovanja i radnog staža ispitanika s odgovorima za procjenu sindroma izgaranja te sindromom izgaranja ocijenjena je Spearmanovim koeficijen- tom korelacije [Tablica 10]. Prikazani rezultati pokazuju da ispitanici višeg stupnja obrazovanja u većoj mjeri osjećaju da rade sve više, a da ništa ne naprave $(r=0,339 ; p<0,05)$. Što su ispitanici stariji, to su više mrzovoljni, brže su raspaljivi te očekuju više od ljudi oko sebe $(r=0,251 ; p<0,05)$. S radnim stažom raste i osjećaj ispitanika da imaju malo toga za reći ljudima $(r=0,294 ; p<0,05)$, ali opada stupanj sindroma izgaranja $(r=-0,265 ; p<0,05)$. Između ostalih ispitivanih parametara nije utvrđena statistički značajna povezanost. 
TABLICA [9] Rezultati raspodjele ispitanika prema stupnju sindroma izgaranja i godinama radnog staža

\begin{tabular}{|c|c|c|c|c|c|c|}
\hline \multirow{3}{*}{ Radni staž (godine) } & \multicolumn{6}{|c|}{ Broj ispitanika (\%) prema sindromu izgaranja } \\
\hline & $\begin{array}{l}\text { izostanak } \\
\text { sindroma }\end{array}$ & $\begin{array}{c}\text { ispitanik u } \\
\text { području rizika }\end{array}$ & $\begin{array}{l}\text { kandidat } \\
\text { za razvoj } \\
\text { sindroma }\end{array}$ & $\begin{array}{c}\text { ispitanik } \\
\text { zahvaćen } \\
\text { sindromom }\end{array}$ & $\begin{array}{c}\text { ispitanik } \\
\text { se smatra } \\
\text { sagorjelim }\end{array}$ & Ukupno \\
\hline & $<25$ & $36-50$ & $26-35$ & $51-65$ & $>65$ & \\
\hline $1-10$ & $7(43,8)$ & $4(25,0)$ & $5(31,2)$ & $0(0,0)$ & $0(0,0)$ & $16(24,6)$ \\
\hline $11-20$ & $1(6,2)$ & $3(18,8)$ & $10(62,5)$ & $2(12,5)$ & $0(0,0)$ & $16(24,6)$ \\
\hline $21-30$ & $1(6,2)$ & $8(50,0)$ & $6(37,5)$ & $1(6,2)$ & $0(0,0)$ & $16(24,6)$ \\
\hline $31-40$ & $1(5,9)$ & $9(52,9)$ & $5(29,4)$ & $2(11,8)$ & $0(0,0)$ & $17(26,2)$ \\
\hline Ukupno & $10(15,4)$ & $24(36,9)$ & $26(40,0)$ & $5(7,7)$ & $0(0,0)$ & $65(100)$ \\
\hline
\end{tabular}

*Hi-2 test, Yates korekcija

TABLICA [10] Ocjena povezanosti odgovora za procjenu sindroma izgaranja i sindroma izgaranja sa starosti, stupnjem obrazovanja i radnim stažom ispitanika

\begin{tabular}{lcc}
\hline & \multicolumn{2}{c}{ Spearmanov koeficijent korelacije } \\
\cline { 2 - 3 } & Dob (godine) & Stupanj obrazovanja \\
\hline Događa li vam se da imate premalo vremena za zabavu ? & 0,117 & 0,116 \\
\hline Osjećate li da imate premalo podrške i pomoći ? & 0,081 & 0,085 \\
\hline Zamarate li se lako i osjećate li se iscrpljeno? & 0,199 & $-0,032$ \\
\hline Imate li osjećaj da radite sve više, a da ništa ne napravite? & 0,160 & $\mathbf{0 , 3 3 9 *}$ \\
\hline Jeste li zajedljivi i sve više razočarani svijetom? & 0,194 & $-0,018$ \\
\hline Osjećate li se žalosno, a ne znate zašto? & 0,034 & $-0,057$ \\
\hline Jeste li zaboravljivi, ne odete na dogovoreni sastanak, često nešto izgubite...? & 0,046 & 0,026 \\
\hline Provodite li sve manje vremena s prijateljima i obitelji ? & 0,167 & 0,108 \\
\hline Jeste li prezauzeti za uobičajene potrebe (telefonski razgovori, čitanje, pisanje...?) & 0,176 & 0,223 \\
\hline Osjećate li se uvijek loše ili ste stalno bolesni ? & 0,115 & 0,041 \\
\hline Osjećate li se smeteno na kraju radnog dana ? & 0,041 & 0,183 \\
\hline Opterećuju li Vas seksualne aktivnosti i stvaraju više problema nego inače ? & 0,131 & 0,163 \\
\hline Osjećate li da imate malo toga reći ljudima ? & 0,187 & 0,154 \\
\hline Uzrujate li se kada Vam u zadnje vrijeme kažu da ne izgledate dobro ? & 0,190 & 0,165 \\
\hline Jeste li mrzovoljni, brzo raspaljivi, očekujete li više od ljudi oko Vas ? & $\mathbf{0 , 2 5 1 *}$ & $-0,159$ \\
\hline Sindrom izgaranja & $-0,234$ \\
\hline
\end{tabular}

*statistički značajno; $p<0,05$

\section{Rasprava}

Sestrinstvo kao profesija razvilo se kao samostalna djelatnost i prepoznato je kao struka u sustavu obrazovanja Republike Hrvatske. Razvoj, kontinuitet i sve složeniji oblici bolesti, zahtijevaju kontinuiranu i cjeloživotnu edukaciju medicinskih sestara. Sindrom izgaranja velik je problem koji ne zahvaća samo medicinske sestre nego i cjelokupan zdravstveni sustav. Globalni plan djelovanja za zdravlje radnika (engl. Worke's health: global plan of action - GPA) u svibnju 2007. godine potvrdile su 193 zemlje članice na Svjetskoj zdravstvenoj skupštini te je prihvaćen i 10-godišnji plan razvoja nacionalnog programa zaštite zdravlja i sigurnosti na radu zaposlenih u djelatnosti zdravstvene zaštite. Sukladno Nacionalnoj strategiji razvoja zdravstva 2012. 2020. godine dužnost svake službe u sustavu zdravstvene zaštite jest razviti specifične programe zaštite zdravlja na radu primjerene svojim potrebama. Svrha je Nacionalnog programa zaštite zdravlja i sigurnosti osoba na radu u djelatnosti zdravstvene zaštite 2015. - 2020. godine očuvanje i unaprjeđenje zdravlja [9]. Uredba o zdravlju i sigurnosti na radu u Europskoj uniji sadrži odredbe koje se mogu primijeniti za psihosocijalne karakteristike posla [10]. Parlament Europske unije usvojio je razlučivost kojom se ističe potreba za usklađivanjem sposobnosti i potreba zaposlenika s karakteristikom posla, odnosno prevenciju neslaganja mogućnosti djelatnika i zahtjeva obujma posla [11].

U Narodnim novinama objavljen je Zakon o zaštiti na radu koji uvodi odredbe o osnivanju Zavoda za unaprjeđivanje zaštite na radu, a Novi zakon prvi put uvodi odredbe o mjerama zašti- 
te radnika od psihosocijalnih rizika (stres) i psihofizioloških napora na radu s ciljem prevencije i edukacije svih sudionika [9].

Rezultati ovog istraživanja, provedenog u svrhu utvrđivanja zastupljenosti sindroma izgaranja na primarnoj i sekundarnoj razini zdravstvene zaštite, upućuju da se u području rizika za razvoj sindroma izgaranja nalaze 24 ispitanika (36,9\%). Među ispitanicima ima 26 kandidata (40 \%) za razvoj sindroma izgaranja. Sindromom izgaranja zahvaćeno je 5 ispitanika (7,7\%). Christina Maslach ističe da se emocionalna iscrpljenost prva javlja u razvoju sindroma izgaranja. Schaufeli i Leiter smatraju da osoba prvo osjeća umor i gubitak snage te volje za dalje investiranje u svoj posao [12]. Iz rezultata provedenog istraživanja vidljivo je sljedeće: ispitanici višeg stupnja obrazovanja u većoj mjeri osjećaju da rade sve više, a da ništa ne naprave $(r=0,339 ; p<0,05)$, što su ispitanici stariji, to su više mrzovoljni, brže su raspaljivi te očekuju više od ljudi oko sebe $(r=0,251 ; p<0,05)$. S radnim stažom raste i osjećaj da imaju malo toga za reći ljudima ( $r$ $=0,294 ; p<0,05)$, ali opada stupanj sindroma izgaranja ( $r$ $=-0,265 ; p<0,05)$. Navedeno potvrđuje da su sindromu izgaranja više sklone osobe na početku karijere, osobe željne dokazivanja i one koje teže višoj poziciji i uspjehu. Razlike srednjih vrijednosti sindroma izgaranja u provedenom istraživanju nisu se pokazale statistički značajnima među skupinama različitog stupnja obrazovanja niti između skupine ispitanika s obzirom na rukovodeće/nerukovodeće radno mjesto. Kada se promatraju samo ispitanici u braku i skupina neudanih/neoženjenih, razlika je statistički značajna: više je ispitanika koji su u braku i imaju viši stupanj sindroma izgaranja u odnosu na neudane/neoženjene. To bi se moglo povezati s privatnim životima ispitanika, odnosno osobe u braku zbog brojnih obaveza vezanih za obiteljski život, imaju manje vremena za rekreaciju, psihički i fizički odmor. Li i suradnici prezentirajući rezultate svojeg istraživanja ističu da predanost organizaciji i grupna kohezija imaju pozitivan učinak na korelaciju izloženosti stresu i posttraumatskim stresnim simptomima te loše ishode zdravstvene njege [13]. Istraživanje koje su proveli Ekić i suradnici potvrđuje da se preopterećenost poslom, odgovornost medicinskih sestara na mjestu rukovoditelja predstavljaju kao najviše stresni [14]. Visoko je ocijenjen stresor i nedostatak vremena potrebnog za skrb o bolesnicima. Također se navodi da se medicinske sestre s višim stupnjem obrazovanja, znanjem i sposobnostima u profesionalnom radu lakše nose sa stresom, prilagođavaju se izvorima stresa te stresnim događajima [14]. Rezultati studije Demerouti i suradnika također potvrđuju da je nedostatak vremena i vremenski pritisak jedan od najčešćih razloga iscrpljenosti [15].

Zdravstveni sustav Republike Hrvatske u 2012. godini bilježi 24262 medicinske sestre (zaposleni na neodređeno vrijeme) te 5881 medicinsku sestru (zaposleni na određeno vrijeme). Od toga je $91 \%$ ženskog spola. Medicinske sestre čine $46 \%$ cjelokupnog broja zdravstvenih djelatnika. Udio sestrinskih intervencija / postupaka iznosi $70 \%$ svih postupaka u zdravstvu [16]. Broj medicinskih sestara u odnosu na popis stanovništava iz 2011. godine (RH, 4284889 stanovnika) iznosi 579/100 000 stanovnika što je znatno manje od prosjeka Europske unije koji za 2011. godinu iznosi 836 sestara na 100000 stanovnika te jasno potvrđuje činjenicu nedostatka i preopterećenosti medicinskih sestara, nedostatak njihova vremena i pojačanu izloženost psihičkom i fizičkom umoru [16]. Sukladno ovim rezultatima, s ciljem prevencije i ublažavanja već izraženih simptoma sagorijevanja, potrebno je provesti aktivnosti edukacija o suočavanju sa stresom putem kojih bi se smanjila pojava određenih ponašanja, a koja utječu na razvoj sindroma sagorijevanja.

\section{Zaključak}

Rezultati provedenog istraživanja pokazuju da je 55 od ukupno 65 ispitanika zahvaćeno nekim stupnjem sindroma izgaranja koji prethodi potpunom izgaranju. Zaključujemo da nedostatak zdravstvenih djelatnika rezultira prevelikom opterećenosti medicinskih sestara na njihovim radnim mjestima, nedostatkom vremena te time pogoduje nastanku sindroma izgaranja. Potrebno je više ulaganja i djelovanja, psihoedukacije, usklađivanja sposobnosti i mogućnosti medicinskih sestara s njihovim radnim zadacima kako bi se omogućila kvalitetnija zdravstvena njega, veće zadovoljstvo pacijenata i medicinskih sestara, a samim time i umanjila mogućnost za nastanak te zahvaćenost sindromom izgaranja.

\section{Nema sukoba interesa}

\section{Authors declare no conflict of interest}

\section{Literatura/References}

[1] Freudenberger H. Staff burn-out. J Soc Issues. 1974; 30: 159-65, DOI:10.1111/j.1540-4560.1974.

[2] H. Freudenberger, G. North, Burnout bei Frauen., Frankfurt am Main: Krüger, 1992.

[3] Hudek-Knežević J, Krapić N, Rajter L. Odnos između emocionalne kontrole, percipiranog stresa na radnom mjestu i profesionalnog sagorijevanja kod medicinskih sestara. Psihologijske teme. 2005; 14 (2): 41-54, ID:11840

[4] WHO/World Health Organization. Available from: http://www.who. int/en/5. Accessed Jun 20, 2018.

[5] Franković S. Sociološki aspekti razvoja sestrinstva kao profesije, diplomski rad, 2004.

[6] Friganović A, Kovačević I, Slijepčević J, Vidmanić S. Psihoedukacija i prevencija sindroma sagorijevanja kod medicinskih sestara. Hrvatski časopis za javno zdravstvo. 2017; 13 (49): 2-10.

[7] Mazzi B, Ferlin D. Sindrom sagorjelosti na poslu: Naš profesionalni problem. IV. kongres HDOD-HLZ. Rovinj: HDOD. Available from: http://www.hdod.net/rad_drustva/RAD\%20-\%20Burnout\%20syndrom\%20-\%202004.pdf. Accessed Jun 20, 2018.

[8] Mrnjec V. Povijesni pregled obrazovanja medicinskih sestara u Republici Hrvatskoj. Sestrinski glasnik/Nursing Journal. 2014; 19 (3): 246-9, DOI: $10.11608 /$ sgnj.2014.19.052

[9] Zakon o zaštiti na radu. Available from: NN 96/18 https://www.zakon. $\mathrm{hr} / \mathrm{z} / 167 /$ Zakon-o-za\%C5\%A1titi-na-radu. Accessed August 3, 2019.

[10] Sigurnost i zdravlje radnika na radu. "Framework Directive". 89/391/ EEC - OSH. 1989. Available from: https://osha.europa.eu/hr/legislation/directives/the-osh.../. Accessed August 3, 2019.

[11] 21st annual activity report of the Advisory Committee on Safety. Hygiene and Health Protection at Work - 1996. Available from: www. europarl.europa.eu/sides/getDoc.do?pubRef=-//EP//TEXT...A4-1999. Accessed August 4, 2019.

[12] Maslach, C., Schaufeli, W.B., Leiter, P.M. Job burnout. Annu Rev Psycho. 2001; 53:397-422, DOI:10.1146/annurev.psych.52.1.397

[13] Li A, Early SF, Mahre NE, Klaristenfeld Jl, Gold Jl. Group cohesion and organizational commitment: protective factors for nurse residents' job satisfaction, compassion fatigue, compassion satisfaction, and burnout. J Prof Nurs. 2014; 30 (1): 89-99, DOI: 10.1016/j.profnurs.2013.04.004

[14] Ekić S, Primorac A, Vučić B. Profesionalni stres kod medicinskih sestara i tehničara. Journal of Applied Health Sciences. 2016; 2(1): 39-46, DOI: $10.24141 / 1 / 2 / 1 / 5$

[15] DeMerouti E, Bakker AB, Nachreiner F, Schaufeli WB. A model of burnout and life satisfaction among Nurses. J Adv Nurs. 2000; 32: 454 64, DOI:10.1046/j.1365-2648.2000.01496.x

[16] Jaman Galeković M. Povezanost sindroma sagorijevanja medicinskih sestara s radnim mjestom i privatnim životom, diplomski rad, 2016. 